\title{
Post-Transcriptional Control of Cytokine Gene Expression in Health and Disease
}

\author{
Khalid S.A. Khabar
}

Post-transcriptional control of cytokine gene expression is essential for rapid and transient response to stimuli and external stress. In health, post-transcriptional control is exerted by a number of trans-acting RNA-binding proteins and cis-acting sequence elements. These elements exist largely in the $3^{\prime}$ untranslated region and comprise microRNA targets and notably AU-rich elements, and exert regulated mRNA decay and translation repression. Defects in this control can lead to increased and sustained production of pro-inflammatory mediators contributing to several chronic inflammatory disease and cancer states. This introduction to the Journal's special issue on the topic summarizes, in a non-comprehensive list, the types of RNA-binding protein and their target cytokines, and potential contributions to disease, and presents the highlights of the individual reviews.

$I^{\prime}$ N THE HEALTHY BODY, cellular post-transcriptional control contributes to rapid cytokine gene expression in response to inflammatory or microbial stimuli while allowing a transient reaction to the inducer. If this control becomes aberrant, then extended and overproduction of proinflammatory cytokines and other mediators will exacerbate certain disease conditions (Khabar 2010). The post-transcriptional control of cytokine expression in health is exerted by trans-acting RNAbinding proteins and cis-acting sequence elements, largely in the $3^{\prime}$ untranslated region (3'UTR), comprising microRNA (miRNA) targets and notably AU-rich elements (ARE). The latter have been of the most extensively studied pattern elements and can pose controlled mRNA instability and translation repression in health. In disease, the post-transcriptional control of cytokines is subject to a number of defects that lead to different abnormalities and conditions. Table 1 outlines a noncomprehensive list of these defects, the types of RNAbinding protein and cytokines involved, and their potential contributions to disease. This special review issue offers updated views on the roles of the post-transcriptional control of cytokine expression and was written by the experts who are not only knowledgeable about the key basic mechanisms, but also about the interrelationships with disease processes.

A prominent example of cytokines that is subject to posttranscriptional control is tumor necrosis factor alpha (TNF$\alpha$ ). Because of its involvement in a number of diseases, it is one of the most often studied cytokines, which has led to antiTNF therapy in recent years (Paulsen and others 2013; Tanaka 2013). Rapid shutoff of TNF- $\alpha$ production after encountering stimuli, such as bacterial endotoxins (lipopolysaccharides), is necessary because of the extreme proinflammatory and cytotoxic action of TNF- $\alpha$ (Kontoyiannis and others
1999). Continued production of TNF- $\alpha$ is a feature observed in chronic inflammatory conditions, such as rheumatoid arthritis. In this review issue, $\mathrm{TNF}-\alpha$ has been widely referred to during the discussions on the post-transcriptional regulation of cytokine expression, either because TNF- $\alpha$ gene is a model of post-transcriptional control investigations or as a key modulator in inflammatory response.

An important pathway that has been extensively studied in ARE-mediated control of cytokine expression is the mitogen-activated protein kinase (MAPK). During demand, for example, as in cellular stress and inflammatory insults, MAPK transiently phosphorylates the mRNA decaypromoting protein, tristetraprolin (TTP/ZFP36) leading to loss of binding to AREs, and subsequently increases cytokine mRNA stability and translation (Hitti and others 2006; Clement and others 2011). However, in certain chronic disease and cancer conditions, where MAPK is continually activated, this transient activity becomes prolonged. In this issue, Gaestel and colleagues review the intricate role of MAPK pathway signaling in cytokine mRNA decay and in translation. They point out both ARE-dependent and AREindependent effects, where the latter encompass mechanisms involving the miRNA pathway (Tiedje and others 2014). Vlasova-St. Louis and Bohjanen continue with a further overview of AREs, including their sequence characteristics and ARE-binding proteins, as they relate to cytokines, particularly T-cell lymphokines. Moreover, they elaborate on the emerging role of GU-rich elements (GREs), which interestingly share structural patterns with AREs such as overlap, number, and specific localization of repeats in 3'UTR (Halees and others 2011). The role of CEFL (also called CUGBP1), which binds and regulates GRE-containing

Department of BioMolecular Research, King Faisal Specialist Hospital and Research Centre, Riyadh, Saudi Arabia. 


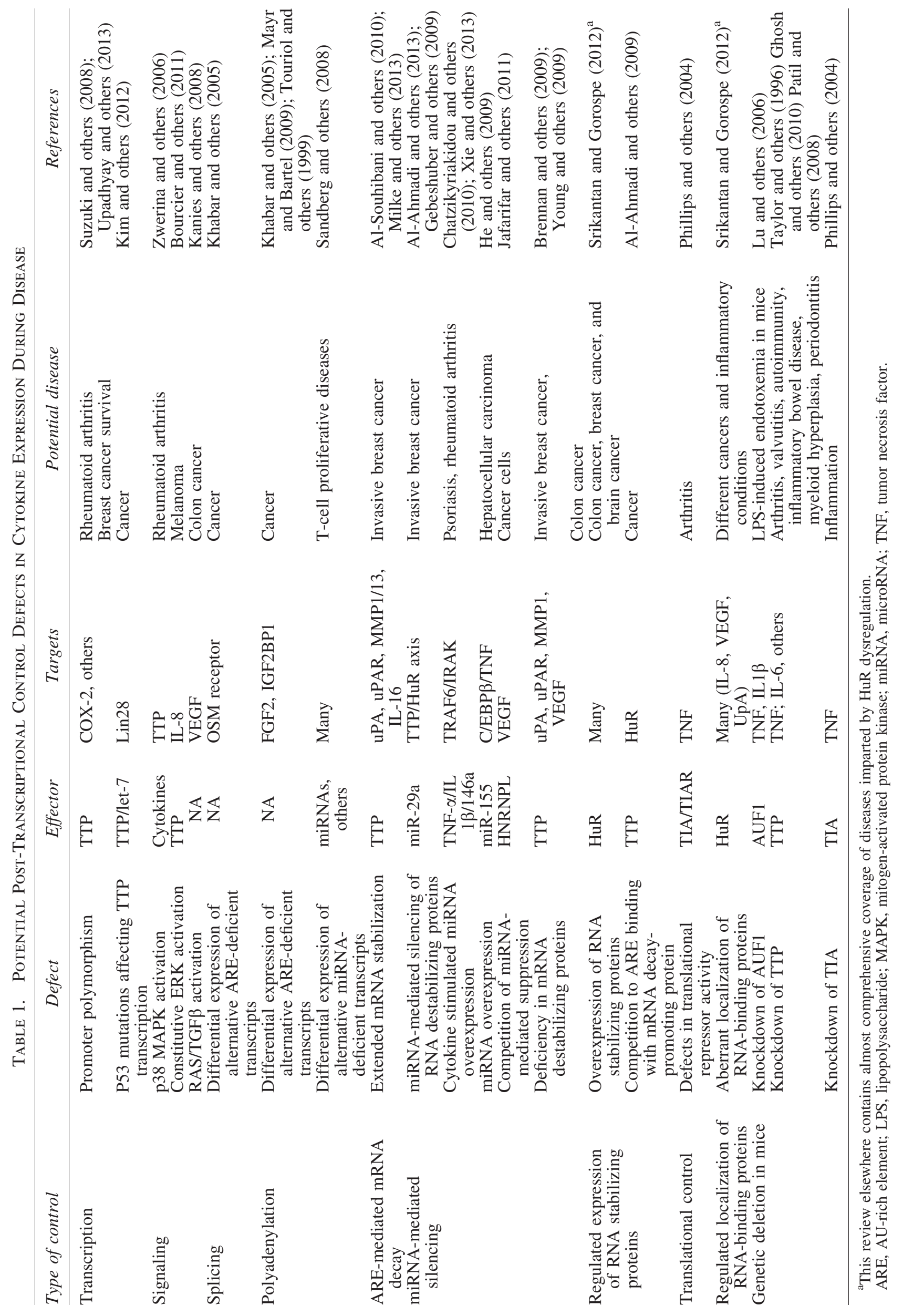


transcripts, is also discussed in the review (Vlasova-St. Louis and Bohjanen 2014).

The abnormalities of the post-transcriptional regulation of cytokine expression in disease are discussed in two reviews in this issue: one focuses on cancer and the other on inflammation. The former addresses the post-transcriptional control of cytokines that promote pro-cancer activities, particularly in angiogenesis (Griseri and Pagès 2014). Thus, angiogenesis is presented, at least partly, as a consequence of the aberrant post-transcriptional control of pro-angiogenic cytokine (such as VEGF) expression. An overall summary of RNA-binding proteins and their role in affecting different types of tumors is also presented in this review. Panganiban and others (2014) include discussions on posttranscriptional control of chemokines in disease, particularly in models of allergic inflammation in human airway epithelium. Chemokines are cytokines that attract various types of immune and nonimmune cells to areas of inflammation or microbial attacks; and thus, transient responses imparted by tight gene regulation are essential for healthy cell trafficking (Hamilton and others 2012). However, in chronic allergic conditions, such as asthma, increased chemokine response is promoted by cytokine-driven activation of RNA-binding protein, such as $\mathrm{Hu}$ antigen $\mathrm{R}$ (HuR/ELAVL1) (Panganiban and others 2014). The latter is a universal RNA stabilitypromoting protein that has attracted attention in the field because of its numerous mRNA targets (Simone and Keene 2013); thus, it has been covered in several reviews here. Another widely discussed RNA-binding protein, in this special issue, is TTP/ZFP36 because of its importance in cytokine mRNA regulation and its aberrations across different conditions and diseases (Table 1). A special topic on the structural and evolutionary aspects of the TTP/ZFP36 family is presented, at the end of the issue (Blackshear and Perera 2014).

Another appreciable portion of the review issue focuses on post-transcriptional regulation of the interferon (IFN) system. IFNs are key proteins that play diverse roles in innate immunity to viruses and in the regulation of the immune system. Regulation of the IFN system, whether during IFN production or during the cellular response to IFN, occurs at many different levels, including posttranscriptional regulation, reviewed earlier (Khabar and Young 2007). Recent work in this area implicated an mRNA decay-promoting RNA-binding protein called KH-type splicing regulatory protein (KSRP) as a negative regulatory factor for IFN production [reviewed here by King and Chen (2014)]. The authors proposed an integrated model for type I IFN post-transcriptional control by KSRP and TTP. Additionally, the role of KSRP in cytokine control and miRNA biogenesis is discussed in the same review (King and Chen 2014).

Ribonuclease L (RNase L) is a part of the IFN system and possesses strong activity against viral mRNAs but has also been proposed as a negative feedback player in IFN response targeting cellular mRNAs (Khabar and others 2003). Hassel's group expands on the role of RNase L as emerging cellular mRNA regulator and discusses the repertoire of known RNase L targets and its consequences in cell cycle and other cellular functions (Brennan-Laun and others 2014). The controlled function of the IFN system allows rapid elimination of microbes and a favorable immunomodulatory action without deleterious consequence for the host. Another important element in IFN action is the contribution of $\mathrm{mTOR} / \mathrm{S} 6 \mathrm{~K}$ and ERK/MNK pathways in IFNstimulated mRNA translation, discussed here in the review by the Platanias group (Brennan-Laun and others 2014). These pathways act on translational regulators, one of which is the translation repressor $4 \mathrm{E}-\mathrm{B}$, which upregulates mRNA translation upon phosphorylation by mTOR during IFN response (Brennan-Laun and others 2014)—also during other selected cytokine responses (Mazumder and others 2010).

The variety of signaling mediators and effectors participating in the post-transcriptional control of cytokine expression indicates a multitude of potential defects that can arise during disease. This knowledge should add to the appreciation of the potential targeting of the perturbed posttranscriptional events for novel and alternative therapeutic approaches. This special issue highlights the significant players and pathways that govern post-transcriptional regulation of cytokine and IFN expression and thus generating rationale for further investigations, including new drug targets for chronic inflammatory conditions, autoimmune diseases, and cancer.

\section{Acknowledgment}

I thank Ms. Marieta Cepec for administrative assistance in the development of this special review issue.

\section{Author Disclosure Statement}

No competing financial interests exist.

\section{References}

Al-Ahmadi W, Al-Ghamdi M, Al-Haj L, Al-Saif M, Khabar KS. 2009. Alternative polyadenylation variants of the RNA binding protein, HuR: abundance, role of AU-rich elements and auto-Regulation. Nucleic Acids Res 37(11):3612-3624.

Al-Ahmadi W, Al-Ghamdi M, Al-Souhibani N, Khabar KS. 2013. miR-29a inhibition normalizes HuR over-expression and aberrant AU-rich mRNA stability in invasive cancer. J Pathol 230(1):28-38.

Al-Souhibani N, Al-Ahmadi W, Hesketh JE, Blackshear PJ, Khabar KS. 2010. The RNA-binding zinc-finger protein tristetraprolin regulates AU-rich mRNAs involved in breast cancer-related processes. Oncogene 29(29):4205-4215.

Blackshear PJ, Perera L. 2014. Phylogenetic distribution and evolution of the linked RNA binding and NOT1 binding domains in the TTP family of tandem $\mathrm{CCCH}$ zinc finger proteins. J Interferon Cytokine Res 34(4):297-306.

Bourcier C, Griseri P, Grepin R, Bertolotto C, Mazure N, Pages G. 2011. Constitutive ERK activity induces downregulation of tristetraprolin, a major protein controlling interleukin8/ CXCL8 mRNA stability in melanoma cells. Am J Physiol Cell Physiol 301(3):C609-C618.

Brennan-Laun SE, Ezelle HJ, Li X-L, Hassel BA. 2014. RNaseL control of cellular mRNAs: roles in biologic functions and mechanisms of substrate targeting. J Interferon Cytokine Res 34(4):275-288.

Brennan SE, Kuwano Y, Alkharouf N, Blackshear PJ, Gorospe M, Wilson GM. 2009. The mRNA-destabilizing protein tristetraprolin is suppressed in many cancers, altering tumorigenic phenotypes and patient prognosis. Cancer Res 69(12):5168-5176.

Chatzikyriakidou A, Voulgari PV, Georgiou I, Drosos AA. 2010. The role of microRNA-146a (miR-146a) and its target 
IL-1R-associated kinase (IRAK1) in psoriatic arthritis susceptibility. Scand J Immunol 71(5):382-385.

Clement SL, Scheckel C, Stoecklin G, Lykke-Andersen J. 2011. Phosphorylation of tristetraprolin by MK2 impairs AU-rich element mRNA decay by preventing deadenylase recruitment. Mol Cell Biol 31(2):256-266.

Gebeshuber CA, Zatloukal K, Martinez J. 2009. miR-29a suppresses tristetraprolin, which is a regulator of epithelial polarity and metastasis. EMBO Rep 10(4):400-405.

Ghosh S, Hoenerhoff MJ, Clayton N, Myers P, Stumpo DJ, Maronpot RR, Blackshear PJ. 2010. Left-sided cardiac valvulitis in tristetraprolin-deficient mice: the role of tumor necrosis factor alpha. Am J Pathol 176(3):1484-1493.

Griseri P, Pagès G. 2014. Control of pro-angiogenic cytokine mRNA half-life in cancer: the role of AU-rich elements and associated proteins. J Interferon Cytokine Res 34(4): 242-254.

Halees AS, Hitti E, Al-Saif M, Mahmoud L, Vlasova-St Louis IA, Beisang DJ, Bohjanen PR, Khabar K. 2011. Global assessment of GU-rich regulatory content and function in the human transcriptome. RNA Biol 8(4):681-691.

Hamilton T, Li X, Novotny M, Pavicic PG, Jr., Datta S, Zhao C, Hartupee J, Sun D. 2012. Cell type- and stimulus-specific mechanisms for post-transcriptional control of neutrophil chemokine gene expression. J Leukoc Biol 91(3):377-383.

He M, Xu Z, Ding T, Kuang DM, Zheng L. 2009. MicroRNA155 regulates inflammatory cytokine production in tumorassociated macrophages via targeting $\mathrm{C} / \mathrm{EBPbeta}$. Cell Mol Immunol 6(5):343-352.

Hitti E, Iakovleva T, Brook M, Deppenmeier S, Gruber AD, Radzioch D, Clark AR, Blackshear PJ, Kotlyarov A, Gaestel M. 2006. Mitogen-activated protein kinase-activated protein kinase 2 regulates tumor necrosis factor mRNA stability and translation mainly by altering tristetraprolin expression, stability, and binding to adenine/uridine-rich element. Mol Cell Biol 26(6):2399-2407.

Jafarifar F, Yao P, Eswarappa SM, Fox PL. 2011. Repression of VEGFA by CA-rich element-binding microRNAs is modulated by hnRNP L. EMBO J 30(7):1324-1334.

Kanies CL, Smith JJ, Kis C, Schmidt C, Levy S, Khabar KS, Morrow J, Deane N, Dixon DA, Beauchamp RD. 2008. Oncogenic Ras and transforming growth factor-beta synergistically regulate AU-rich element-containing mRNAs during epithelial to mesenchymal transition. Mol Cancer Res 6(7):1124-1136.

Khabar KS. 2010. Post-transcriptional control during chronic inflammation and cancer: a focus on AU-rich elements. Cell Mol Life Sci 67(17):2937-2955.

Khabar KS, Bakheet T, Williams BR. 2005. AU-rich transient response transcripts in the human genome: expressed sequence tag clustering and gene discovery approach. Genomics 85(2):165-175.

Khabar KS, Siddiqui YM, al-Zoghaibi F, al-Haj L, Dhalla M, Zhou A, Dong B, Whitmore M, Paranjape J, Al-Ahdal MN, Al-Mohanna F, Williams BR, Silverman RH. 2003. RNase L mediates transient control of the interferon response through modulation of the double-stranded RNA-dependent protein kinase PKR. J Biol Chem 278(22):20124-20132.

Khabar KS, Young HA. 2007. Post-transcriptional control of the interferon system. Biochimie 89(6-7):761-769.

Kim CW, Vo MT, Kim HK, Lee HH, Yoon NA, Lee BJ, Min YJ, Joo WD, Cha HJ, Park JW, Cho WJ. 2012. Ectopic overexpression of tristetraprolin in human cancer cells promotes biogenesis of let-7 by down-regulation of Lin28. Nucleic Acids Res 40(9):3856-3869.
King PH, Chen C-Y. 2014. Role of KSRP in control of type I interferon and cytokine expression. J Interferon Cytokine Res 34(4):267-274.

Kontoyiannis D, Pasparakis M, Pizarro TT, Cominelli F, Kollias G. 1999. Impaired on/off regulation of TNF biosynthesis in mice lacking TNF AU-rich elements: implications for joint and gut-associated immunopathologies. Immunity 10(3):387-398.

Lu JY, Sadri N, Schneider RJ. 2006. Endotoxic shock in AUF1 knockout mice mediated by failure to degrade proinflammatory cytokine mRNAs. Genes Dev 20(22):3174-3184.

Mayr C, Bartel DP. 2009. Widespread shortening of 3'UTRs by alternative cleavage and polyadenylation activates oncogenes in cancer cells. Cell 138(4):673-684.

Mazumder B, Li X, Barik S. 2010. Translation control: a multifaceted regulator of inflammatory response. J Immunol 184(7):3311-3319.

Milke L, Schulz K, Weigert A, Sha W, Schmid T, Brune B. 2013. Depletion of tristetraprolin in breast cancer cells increases interleukin-16 expression and promotes tumor infiltration with monocytes/macrophages. Carcinogenesis 34(4):850-857.

Panganiban RP, Vonakis B, Ishmael FT, Stellato C. 2014. Coordinated posttranscriptional regulation of the chemokine system: messages from CCL2. J Interferon Cytokine Res 34(4):255-266.

Patil CS, Liu M, Zhao W, Coatney DD, Li F, VanTubergen EA, D'Silva NJ, Kirkwood KL. 2008. Targeting mRNA stability arrests inflammatory bone loss. Mol Ther 16(10): 1657-1664.

Paulsen MT, Veloso A, Prasad J, Bedi K, Ljungman EA, Tsan YC, Chang CW, Tarrier B, Washburn JG, Lyons R, Robinson DR, Kumar-Sinha C, Wilson TE, Ljungman M. 2013. Coordinated regulation of synthesis and stability of RNA during the acute TNF-induced proinflammatory response. Proc Natl Acad Sci U S A 110(6):2240-2245.

Phillips K, Kedersha N, Shen L, Blackshear PJ, Anderson P. 2004. Arthritis suppressor genes TIA-1 and TTP dampen the expression of tumor necrosis factor alpha, cyclooxygenase 2, and inflammatory arthritis. Proc Natl Acad Sci U S A 101(7):2011-2016.

Sandberg R, Neilson JR, Sarma A, Sharp PA, Burge CB. 2008. Proliferating cells express mRNAs with shortened 3' untranslated regions and fewer microRNA target sites. Science 320(5883):1643-1647.

Simone LE, Keene JD. 2013. Mechanisms coordinating ELAV/ Hu mRNA regulons. Curr Opin Genet Dev 23(1):35-43.

Srikantan S, Gorospe M. 2012. HuR function in disease. Front Biosci (Landmark Ed) 17:189-205.

Suzuki T, Tsutsumi A, Suzuki H, Suzuki E, Sugihara M, Muraki Y, Hayashi T, Chino Y, Goto D, Matsumoto I, Ito S, Miyazawa K, Sumida T. 2008. Tristetraprolin (TTP) gene polymorphisms in patients with rheumatoid arthritis and healthy individuals. Mod Rheumatol 18(5):472-479.

Tanaka Y. 2013. Next stage of RA treatment: is TNF inhibitorfree remission a possible treatment goal? Ann Rheum Dis 72 Suppl 2:ii124-ii127.

Taylor GA, Carballo E, Lee DM, Lai WS, Thompson MJ, Patel DD, Schenkman DI, Gilkeson GS, Broxmeyer HE, Haynes BF, Blackshear PJ. 1996. A pathogenetic role for TNF alpha in the syndrome of cachexia, arthritis, and autoimmunity resulting from tristetraprolin (TTP) deficiency. Immunity 4(5):445-454.

Tiedje C, Holtmann H, Gaestel M. 2014. The role of mammalian MAPK signaling in regulation of cytokine mRNA stability and translation. J Interferon Cytokine Res 34(4): 220-232. 
Touriol C, Morillon A, Gensac MC, Prats H, Prats AC. 1999. Expression of human fibroblast growth factor 2 mRNA is post-transcriptionally controlled by a unique destabilizing element present in the 3'-untranslated region between alternative polyadenylation sites. J Biol Chem 274(30):2140221408.

Upadhyay R, Sanduja S, Kaza V, Dixon DA. 2013. Genetic polymorphisms in RNA binding proteins contribute to breast cancer survival. Int J Cancer 132(3):E128-E138.

Vlasova-St. Louis I, Bohjanen PR. 2014. Posttranscriptional regulation of cytokine signaling by AU-rich and GU-rich elements. J Interferon Cytokine Res 34(4):233-241.

Xie Y-F, Shu R, Jiang S-Y, Liu D-L, Ni J, Zhang X-L. 2013. MicroRNA-146 inhibits pro-inflammatory cytokine secretion through IL-1 receptor-associated kinase 1 in human gingival fibroblasts. J Inflamm 10(1):20.

Young LE, Sanduja S, Bemis-Standoli K, Pena EA, Price RL, Dixon DA. 2009. The mRNA binding proteins HuR and tristetraprolin regulate cyclooxygenase 2 expression during colon carcinogenesis. Gastroenterology 136(5):1669-1679.

Zwerina J, Hayer S, Redlich K, Bobacz K, Kollias G, Smolen JS, Schett G. 2006. Activation of p38 MAPK is a key step in tumor necrosis factor-mediated inflammatory bone destruction. Arthritis Rheum 54(2):463-472.

Address correspondence to: Dr. Khalid S.A. Khabar Department of BioMolecular Research King Faisal Specialist Hospital and Research Centre P3354, MBC-03, Takhasusi Road Riyadh 11211 Saudi Arabia

E-mail: khabar@kfshrc.edu.sa

Received 20 December 2013/Accepted 20 December 2013 